\title{
MAKNA PENDIDIKAN AGAMA KRISTEN DALAM ALKITAB
}

\author{
Steven Tubagus \\ Sekolah Tinggi Teologi Injili Setia Siau \\ tubagussteven@gmail.com
}

\begin{abstract}
This paper aims to describe the meaning of Christian Religious Education in the Bible. The method used is text analysis following the principles of exegesis. The results are: First, the knowledge gained is that believers always rely on God in their lives and are blameless so that they receive God's Revelation. God's revelation affects everyone, both believers and non-believers. The words of Revelation have so much weight and power. Second, those who know Jesus have life in God because Jesus said this is eternal life. Christian religious education seeks to unite humans with God. Education is basically influenced by and must be based on religion, starting from the family, church and society.
\end{abstract}

Keywords: Mean, Christian education, Bible

\begin{abstract}
Abstrak. Tulisan ini bertujuan mendeskripsikan makna Pendidikan Agama Kristen dalam Alkitab. Metode yang digunakan adalah analisis teks sesuai dengan prinsip-prinsip eksegesis. Hasilnya adalah: Pertama, pengetahuan yang didapat adalah orang percaya yang selalu mengandalkan Tuhan di dalam hidupnya dan tidak bercacat sehingga mereka menerima Wahyu Allah. Wahyu Allah mempengaruhi setiap orang, baik orang percaya maupun bukan orang percaya. Kata-kata dalam Wahyu begitu berbobot dan mempunyai kuasa. Kedua, orang yang mengenal Yesus berarti memiliki hidup didalam Tuhan, sebab Yesus berkata inilah hidup yang kekal. Pendidikan Agama Kristen berusaha mempertemukan manusia dengan Allah. Pendidikan pada dasarnya dipengaruhi oleh dan harus didasarkan pada agama, mulai dari keluarga, gereja maupun masyarakat.
\end{abstract}

Kata kunci: Makna, Pendidikan Agama Kristen, Alkitab

\section{PENDAHULUAN}

Menurut tuduhan, dikatakan pada abad ke-2 bahwa orang-orang Kristen melanggar norma-norma kesusilaan. Mengingat tingkah laku yang tidak susila yang dilakukan oleh banyak orang kafir, maka amat mengherankan tuduhan itu. Namun, dari segi musuh para warga Kristen, mungkin logislah pendapat mereka. 
BONAFIDE: Jurnal Teologi dan Pendidikan Kristen

www.jurnal.sttissiau.ac.id/Volume 2/Nomor 1/Juni 2021/hal. 25-45

Orang-orang Kristen condong menarik diri dari semua upacara umum yang bersifat keagamaan. Mereka berkumpul secara rahasia.berdasarkan keterangan yang kurang lengkap, lahan semacam itu agak subur bagi pertumbuhan desasdesus yang tidak benar. Demikianlah orang-orang bukan Kristen percaya bahwa kaum kristen minum darah, makan daging tatkala mereka beribadah, dan itu adalah anak bayi manusia, katanya. Pembicaraan yang banyak tentang cinta kasih, secara wajar menimbulkan pendapat bahwa para warga Kristen itu berzinah pula sebagian integral dari upacara kebaktian mereka. Berbeda dengan orang yang hidup benar dalam kehidupan sehari-hari dengan berdoa pagi, siang, dan malam mencari Tuhan, dan membaca firman Tuhan setiap hari. Baik di dalam dunia pendidikan maupun disekuler orang benar selalu percaya bahwa mempunyai Allah yang benar yang menciptakan manusia yang begitu sempurna, sehingga anak-anak orang benar selalu mendapat perhatian khusus dari Alllah, apa yang di minta oleh anak-anak orang benar selalu diberikan oleh Allah. (Berkhof dan Til 2013). Kehidupan orang benar bertentangan dengan kehidupan orang yang kehidupan tidak benar, orang yang tidak hidup benar setiap harinya hanya memikirkan dosa, mereka hanya memikirkan hawa nafsu, sehingga tidak ada malu lagi

Hal ini menjadi daya tarik buat seorang pengajar, untuk mengajarkan kebenaran, bahwa pendidikan agama kristen berbasiskan kebenaran firman Tuhan di dalam 2Timotius 3:16 yaitu orang-orang benar berhak menjadi seorang pengajar karena mereka selalu mendapat ilham dari Tuhan, apa yang mereka 
ajarkan itu pasti kebenaran firman Tuhan yang akan memberikan penghiburan, kekuatan, jawaban atas doa. Pengajar Kristen mengajarkan anak-anak supaya menjadi anak-anak yang takut akan Tuhan. Sehingga berbicara harus sesuai dengan firman Tuhan karena Alkitab merupakan dasar bagi iman yang hidup di mana melalui Alkitab Allah berbicara kepada umat-Nya (Cully 2011).

Akhirnya, perlu dikemukakan dalam hubungan ini bahwa para pendidik Kristen berusaha menentang keras tuduhan seakan-akan agama mereka hanya cocok bagi anak-anak dan wanita, yaitu mereka yang tidak berpendidikan. Origenes, seorang teolog abad ke-3, menjawab mereka melalui karyanya yang terkenal, yaitu Contra Celsum (melawan Kelsus). Walaupun para pembaca bukan orang Yahudi, ia memanfaatkan baik Perjanjian Lama maupun Perjanjian Baru. Ia mencatat fakta bahwa banyak pemimpin gereja yang dapat digolongkan dalam kelompok cendekiawan yang tidak membatasi penyelidikannya pada sumber imannya saja. Melainkan mencakup juga tulisa-tulisan yang bukan dari pena orang Kristen. Origenes berusaha menyakinkan kaum cendekiawan kafir bahwa iman Kristen merupakan filsafat yang berintegritas dan juga suatu agama yang tinggi. Di samping itu, iman Kristen mendorong terbentuknya perilaku moral dalam diri para penganut (Boehlke 2016a). Pernyataan itu berakar dari sejarah, cerita-cerita, peristiwa-peristiwa dan tradisi suatu bangsa tertentu, serta berpusat pada pribadi Yesus Kristus. Penelitian ini bertujuan berusaha untuk mencari makna dalam tulisan yang diilhamkan Allah, apa yang diilhamkan Allah, tulisanNya atau penulisnya. Sehingga bisa dimengerti tulisan yang benar, yang mendidik 
lewat perkataan dan kehidupan orang benar, apa yang baik pasti akan menghasilkan kebaikan.

\section{METODE}

Penelitian kualitatif dengan memakai metode literatur Alkitab secara deskriptif dengan menganalisis sumber-sumber primer dan sekunder dari bukubuku sesuai dengan topik pembahasan (Sugiyono 2015). Akhirnya, penelitian peneliti disatukan melalui perpaduan deskripsi, penafsiran dan analisis (Tohirin 2012). Dengan begitu akan mudah untuk mengambil kesimpulan berdasarkan pembahasan yang sesuai dengan maksud teks dan konteks aslinya. Dengan demikian semua pertanyaan dan perdebatan yang menyangkut konteks ini yang dianggap sudah tidak relevan bagi gereja masa kini terjawab dengan benar dalam kesimpulan.

\section{HASIL PENELITIAN}

Yang pertama adalah pengenalan terhadap Allah. Manusia perlu mengenal Allah sehingga perlu diperdamaikan dengan Allah sebagai pencipta yang memimpin dan memberikan seluruh kehidupan. Mengenal Juru selamat dunia yaitu Yesus Kristus, yang telah menebus dosa kita semua di atas kayu salib.

Yang kedua, pengenalan dan pengalaman akan Roh Kudus. Kehidupan rohani murid-murid PAK harus berkembang dan berbuah banyak karena dikuasai oleh Roh Kudus. Pengenalan dan pandangan hidup secara Kristen, supaya belajar memandang dan menilai segala gejala di dunia disekitarnya itu berdasarkan Alkitab. 
Yang ketiga, menjadi alat Tuhan untuk menyampaikan warisan agama Kristen kepada generasi baru. Menjadi alat Tuhan yaitu mengenal kebenaran berdasarkan Alkitab, menjadi alat Tuhan untuk mewarisi kebenaran akan firman Tuhan yang membawa pertobatan, supaya setiap orang beroleh kehidupan kekal.

\section{PEMBAHASAN}

\section{Menerima Pengetahuan}

Pengetahuan yang didapat adalah orang percaya yang selalu mengandalkan Tuhan di dalam hidupnya dan tidak bercacat sehingga mereka menerima Wahyu Allah yang mempengaruhi setiap orang, baik orang percaya maupun bukan orang percaya. Kata-kata dalam Wahyu begitu berbobot dan mempunyai kuasa. Bila orang sakit mendengar Wahyu Allah maka orang sakit itu akan sembuh. Bila orang yang sakit lumpuh, mendengar Wahyu Allah maka orang sakit lumpuh itu akan sembuh dari sakit lumpuh dan dia bisa berjalan. Bila seorang yang buta dari lahir mendengar Wahyu Allah maka orang yang buta dari lahir itu akan sembuh dan dia bisa melihat seperti orang yang normal dan bila orang tuli mendapat Wahyu Allah, maka ia akan sembuh dari tuli dan bisa mendengar. Wahyu itu berotoritas dan penuh dengan kuasa.. Berdasarkan pandangan ini. Dalam pengertian tertentu Allah telah menyatakan diri-Nya kepada setiap orang. Kita juga dapat berbicara secara empati tentang akibat-akibat dari pencemaran akibat kejatuhan manusia terhadap pengetahuan.

Sedemikian tercemarnya, sehingga orang berdosa melenyapkan Allah sekaligus dari pikirannya. Wahyu Allah secara benar tidak berpengaruh terhadap 
pemikirannya. (1) menurut ini, kita dapat mengatakan bahwa Allah menyatakan diri-Nya kepada umat yang berdosa, tentunya orang berdosa punya pengetahuan akan Allah, tetapi mereka tidak percaya kepada Allah. (2) Alkitab mengatakan hanya orang benar saja yang bisa berbicara langsung dengan Allah. (Roma $1: 23,25)$.

Menurut Alkitab, orang percaya atau orang tidak percaya akan berbicara tentang Allah(Frame 1999). Manusia yang berdosa tentunya manusia yang takut bertemu dengan Tuhan, kenapa merasa takut karena ada kesalahan yang dibuat. Kesalahan itulah yang menjauhkan kita dengan Allah. Penyataan Allah tidak lagi kita terima karena dosa yang menghalangi kita. Pertobatanlah yang membuat kita bisa bertemu dengan Allah

Pengetahuan dan inkomprehensibilitas Allah. Allah tidak bisa digambarkan dan ucapkan dengan kata-kata. Tidak seorangpun pernah mengenal Dia, kecuali sejauh Ia telah menyatakan diri-Nya. Akan tetapi, Ia tidak membiarkan kita dalam ketidaktahuan. Ia telah menanamkan pengetahuan akan eksistensi-Nya di dalam seluruh alam. Lebih dari itu, dalam Kitab Taurat dan Kitab Para Nabi dan kemudian dalam Kristus, Ia telah menyatakan diri-Nya sejauh yang mungkin kita pahami. Karena itu, kita tidak mencari apa pun yang melampaui kita, kita mengungkapkan diri kita menurut kapasitas kita yang terbatas. Kita mengakui bahwa Allah, di antara perihal-perihal lainnya, adalah kekal dan tidak berubah (Letham 2008). Allah telah memperlengkapi jiwa manusia dengan akal budi supaya demikian kita mengenal bapa. 
Sejauh ini pernyataan Allah yaitu Allah menyatakan diri-Nya, bisa dipahami dan diterima bagi yang percaya. Tidak mengenal Yesus berarti tidak menerima penyataan Allah. Respon terhadap penyataan itu adalah perubahan kehidupan, meninggalkan masa lalu, fokus pada masa kini, dan panggilan baru di masa depan. Penyataan Allah memberikan orientasi hidup manusia, norma untuk mengevaluasi pengetahuan dan tindakan manusia. Selain itu juga mempersatukan aneka dimensi kehidupan manusia, serta menghidupkan kreatifitas untuk bersaksi. Dengan menerima penyataan Allah berarti mengalami klaim tertinggi dalam kesetiaan kita, yang menjadi ukuran bagi semua hal (Lefebure 2003).

Pendidikan Agama Kristen adalah bersumber pada Alkitab. Yang berlandaskan kebenaran untuk mengajarkan cara hidup benar dan hidup kudus di dalam kehidupan sehari-hari, lewat perkataan dan perbuatan menjadi contoh teladan kehidupan orang percaya. Sehingga pendidikan wajib diberikan bagi setiap orang, supaya kehidupan menjadi berarti di dalam Kristus. Orang benar hidup dalam sukacita sedangkan orang yang tidak benar di dalam dosa. Kehidupan Kristus yang taat menyiapkan Dia untuk bagian utama dari karya keselamatan-Nya. Peran ketaatan yang dimainkan dalam kematian-Nya itu signifikan: "Sesungguhnya, bahkan dalam kematian itu sendiri, ketaatan-Nya yang sukarela merupakan hal penting karena suatu korban yang tidak diberikan dengan sukarela tidak akan memajukan kebenaran." Di sini Calvin menekankan kemanusiaan Kristus yang sungguh-sungguh ketika ia mengajarkan, dan mengutip delapan ayat Kitab Suci, bahwa Kristus menyelamatkan kita melalui pergumulan 
BONAFIDE: Jurnal Teologi dan Pendidikan Kristen

www.jurnal.sttissiau.ac.id/Volume 2/Nomor 1/Juni 2021/hal. 25-45

(Lillback 2008). Pendidikan Kristen bertujuan mengenalkan Kristus sebagai Juru selamat dunia. Perbedaan hidup orang benar dan orang yang hidup tidak benar. Kehidupan orang benar selalu mengandalkan Tuhan dan menjauhi kehidupan yang bebas yang terikat pada dosa sedangkan kehidupan orang yang tidak benar selalu berbuat dosa.

PAK merupakan pemupukan akal orang-orang percaya bersama anak-anak mereka dengan firman Tuhan melalui berbagai pembelajaran dalam gereja. Dengan begitu akan dihasilkan pertumbuhan rohani yang nampak melalui karya nyata berupa tindakan-tindakan kasih kepada sesamanya. Demikianlah gereja wajib mengajarkan isi Alkitab dan cara menafsirkannya. Serentak dengan usaha memperdalam pengetahuan dan pengertian Alkitab dalam setiap warga mesti ada tantangan kepadanya sehingga dipertimbangkannya cara yang paling tepat bagaimana mewujudkan pemilihannya dalam kehidupannya. Kehadirannya dalam masyarkat tidak dapat tidak mengubah haluannya. Jadi walaupun pendidikan memperkaya setiap warga, namun Calvin kurang sabar terhadap warga yang terlampau banyak mawas diri seakan-akan keadaan jiwanya lebih penting ketimbang pelaksanaan tugas yang diberikan kepadanya oleh Tuhan (Boehlke 2016a). Janganlah dilupakan bahwa mereka bukanlah kepunyaan sendiri; mereka kepunyaan Tuhan. Tujuan pokok dalam pendidikan agama Kristen hendaknya mencerminkan identitas.

Berbeda dengan kaum imam yang melayani Tuhan dari mesbah, nabi-nabi merasa dirinya terpanggil mengumumkan firman teguran, hukuman dan 
pendamaian. Mereka yakin bahwa Allah menyatakan diri melalui peristiwaperistiwa bersejarah dan alamiah yang tidak dipedulikan kebanyakan orang, misalnya fakta perhatian Allah terhadap negeri sekeliling Israel dan akhirnya Israel itu sendiri Amsal 1-2, Ams. 1:7 "Takut akan TUHAN adalah permulaan pengetahuan, tetapi orang bodoh, menghina hikmat dan didikan”.

Persoalan alamiah yang dilihat di Amos 1-2 sebagai peringatan dan bukan hanya sebagai peristiwa alamiah saja (Amos 4-6-19). Antara peringatan dan hukuman selalu ada waktu sedikit untuk bertobat dan mulai mengamalkan syaratsyarat dari perjanjian mereka dengan Tuhan. Para nabi condong memihak kepada kaum rendah, orang-orang yang dianggap kurang penting oleh kaum atasan.

Tujuan PAK ialah agar semua orang, tanpa kecuali, berkembang pesat dalam ilmu, akhlak, dan kesalehan. Dengan demikian semua orang terdidik dengan baik dalam semua hal yang diperlukan untuk hidup di masa kini (Boehlke 2016b). Tujuan umumnya itu melibatkan orang dalam upaya mencapai tiga potensi yaitu pengetahuan, kebajikan dan kesalehan.

Karena itu, PAK harus digali dari dalam Alkitab, tempat Allah menyatakan rahasia keselamatan-Nya kepada umat-Nya. Alkitab adalah satusatunya sumber pengetahuan mengenai rancangan keselamatan Allah. Alkitablah juga yang memberikan gambaran yang utuh mengenai PAK yang seharunya. Dalam Perjanjian Lama termuat kesaksian mengenai karya-karya besar Allah yang dialami umat Tuhan melalui sejarah. Demikian pula dalam Perjanjian Baru, 
BONAFIDE: Jurnal Teologi dan Pendidikan Kristen

www.jurnal.sttissiau.ac.id/Volume 2/Nomor 1/Juni 2021/hal. 25-45

segala kitabnya ditulis untuk mengajar umat Kristen tentang pernyataan Allah dalam Yesus Kristus (Homrighausen dan Enklaar 2015)

\section{Mengenal Yesus Kristus}

Perjumpaan-Nya dengan perempuan Siro-Fenisia, Yesus mempertimbangkan berbagai opsi untuk menghadapi permintaan tolong perempuan itu. Ini seperti dihadapkan pada situasi kritis dan mendapati bahwa kumpulan jawaban kuno tidak dapat dipakai lagi. Yesus mengambil opsi dengan mengikutsertakan perempuan itu dalam dialog yang jujur. Ini adalah dialog yang baik karena Yesus membuka diri-Nya pada suatu pertukaran (exchange) yang jujur dengan perempuan itu, mitra dialognya, mendengarkan pandangan perempuan itu dan argumentasi tandingannya. Dalam dialog yang jujur seperti itu, Yesus mengambil resiko belajar dari perempuan yang akhirnya memang justru mengajari-Nya dan meninjil-Nya (Antone 2015).

PAK merupakan sebuah upaya menghubungkan manusia dengan Tuhan. Mestinya pendidikan itu seluruhnya bersifat agama sebab sesungguhnya seluruh wilayah kehidupan manusia dipengaruhi dan dikuasai agama. Pendidikan itu dimulai dari keluarga, lalu diteruskan dalam gereja melalui pengajaran tentang Yesus Kristus. Tuhan merupakan pusat dan tujuan pendidikan bangsa Israel. Sebab itu semua hal terkait dengan masyarakat umum perlu dipelajari dan diatur dalam terang Firman Tuhan (Homrighausen dan Enklaar 2015).

Kita perlu berhati-hati dalam mendefinisikan "proposisional." Pertama, pernyataan bukan hanya bersifat informasi tetapi juga bersifat personal dan 
BONAFIDE: Jurnal Teologi dan Pendidikan Kristen

www.jurnal.sttissiau.ac.id/Volume 2/Nomor 1/Juni 2021/hal. 25-45

penebusan: maksudnya Allah menyatakan diriNya kepada manusia, dan melakukan hal ini supaya membangkitkan iman mereka dalam anugerah keselamatan-Nya. Isi pernyataan proposisional bukan informasi untuk informasi semata, tetapi mempunyai maksud personal dan penebusan. Kedua, istilah "proposisional" menimbulkan harapan yang menyesatkan. Orang awam cenderung memikirkannya sebagai pernyataan Allah yang berkenaan dengan kejadian dan situasi historis dengan signifikansi moral, teologis, dan penyelamatan yang di tafsirkan oleh para penulis Alkitab.

Istilah "proposisional" ini bermanfaat jika kita memahami bahwa pernyataan Alkitab itu memiliki isi kognitif, bahwa ia menginformasikan kepada kita kejadian-kejadian yang bersifat pewahyuan dengan maknanya, dan bahwa ia adalah benar, dalam pengertian dapat dipercaya dan memberikan penilaian yang benar. Sebagian tradisi filsafat memikirkan proposal sebagai sesuatu yang bersifat ekstra-linguistik dan ekstra moral, sesuatu yang apa adanya secara obyektif. Dengan cara berfikir demikian, pernyataan proposisional lebih merupakan suatu obyektifitas metafisik" tentang Allah dan bagaimana Ia memperlakukan manusia (Groome 2011). Orang-orang Kristen satu sama lain hanya berbicara mengenai makna Allah bagi kehidupan kita, kita menganggap bahwa kita adalah satusatunya umat yang kepada kita Allah pernah menyatakan diri-Nya, bahwa kita adalah satu-satunya umat yang Allah aktif. Tetapi sumber ini seluruhnya saling berhubungan membantu seluruh gereja yang berusaha mendapatkan dan mengajarkan kebenaran. 
Selama masa pencerahan, perngertian pernyataan proposisional yang lebih terbatas menjadi pandangan yang banyak diterima. Misalnya, John Lock, mendefinisikan penyataan sebagai komunikasi dari proposisi-proposisi yang benar, sebagian melampaui apa yang ditemukan hanya oleh rasio. Ia menganggap pengetahuan sebagai penggabungan dan pemisahan dari ide-ide yang jelas dan terpilah-pilah secara murni obyektif: penalaran kita mulai dari intuisi yang sederhana atau ide-ide empiris, lalu menggabungkannya menjadi ide yang lebih kompleks dan kemudian menarik kesimpulan. Jadi, pengetahuan saya mengenai orang lain didasarkan pada argumen dari analogi antara apa yang saya amati mengenai perilaku fisik saya dan apa yang saya amati megenai orang lain. Pengetahuan saya mengenai eksistensi Allah disimpulkan dari ide intuitif mengenai keberadaan diri saya. Kebenaran terdirr dari kesesuaian antara ide-ide dan penilaian saya terhadap obyek-obyek di luar, dengan demikian pengetahuan hanyalah suatu kopi mental mengenai sesuatu, dimana pikiran saya berkorespondensi dengannya. Bagi Locke, penyataan sesuai pola ini, yang menolong kita dalam membuat kesimpulan mengenai Allah dan karya-Nya yang sulit dan yang terkadang tidak mungkin kita lakukan adalah dengan memberikan kepada kita proposisi yang benar dan yang mengatasi dan melampaui apa yang dapat kita ketahui melalui sarana alamiah. Kebenarannya hanya terdiri dari korespondensi dari proposisinya dengan fakta-fakta obyektif yang diungkapkannya. Tentu saja, pengetahuan kita mengenai Allah merupakan pengetahuan mengenai proposisi-proposisi yang benar mengenai Allah, 
BONAFIDE: Jurnal Teologi dan Pendidikan Kristen

www.jurnal.sttissiau.ac.id/Volume 2/Nomor 1/Juni 2021/hal. 25-45

sebagaimana pengetahuan kita mengenai orang lain terdiri dari proposisi-proposisi yang benar mengenai mereka (Holmes 2009). Permasalahan dalam cara berpikir ini ialah ia membatasi pengetahuan pada suatu kesadaran obyektf mengenai proposisi yang benar tanpa pengalaman dari suatu pribadi yang lebih utuh, dengan demikian ia menerima kebenaran proposisi yang terlepas dari fidelitas.

Menurut Yoh. 17:3 orang yang mengenal Yesus berarti memiliki hidup di dalam Tuhan, sebab Yesus berkata inilah hidup yang kekal. Siapa yang tidak mau menerima hidup yang kekal, pastinya setiap manusia mau menerima hidup yang kekal. Tapi tidak semua orang akan menerimanya. Orang kafir tidak punya tempat di sorga karena orang kafir tidak menerima Yesus sebagai Tuhan dan Juru selamat. Orang kafir menantikan seorang raja yang gagah perkasa yang akan menyelamatkan mereka dari orang jahat, dari kemiskinan tapi mereka mengeraskan hati mereka sehingga mereka tidak menerima keselamatan.

Yesus mengasihi orang kafir. Yesus mau semua ciptaannya diselamatkan dan mau menerima keselamatan. Gagasan Alkitab ialah pengetahuan yang terjadi secara sadar akan lebih bisa menerima pernyataan Allah, karena pernyataan tidak bisa diterima dengan secara tidak sadar. Manusia yang selalu menyembah berhala terutama yang menyembah patung manusia atau patung binatang yang ada di rumah mereka itu yang menunjukkan kebenaran ditindas oleh kebodohan manusia.

Paulus berkata semua yang ku anggap benar sekarang ku anggap sampah oleh karena Dia. Kebodohan yang menjadi sampah oleh manusia, yang tetap di 
pertahankan padahal Yesus sudah menyatakan diri lewat pribadi mereka masingmasing. Yesus merasakan hal yang sama seperti manusia alami, Yesus berdoa dan juga Ia menangis melihat kelakuan manusia (Boehlke 2016b). Begitu banyak orang yang tidak percaya merasa senang bahwa Yesus dipukul, diludah, ditumbak, dan disalibkan. Padahal Yesus menebus mereka dari dosa yang mereka perbuat demikian hakekat Tuhan diperkenalkan lewat manusia (2 Kor. 5:19). Allah mendamaikan dunia dengan diri-Nya oleh Kristus tanpa memperhitungkan pelanggaran mereka. Penyataan Allah yang langsung itu memuncak didalam firman yang menjadi manusia (Hadiwijono 2003). Kasih Yesus nyata didalam kehidupan orang percaya atau benar.

\section{Menerima Janji Yaitu Kehidupan Kekal}

Mimpi adalah pernyataan langsung Allah kepada manusia. Daniel selalu mendapat mimpi. Daniel lewat mimpi sudah tahu apa yang terjadi. Yusuf selalu mendapat mimpi. Orang tua Yusuf percaya mimpi itu akan menjadi kenyataan. Bahkan lewat mimpi Yusuf, saudara-saudaranya membenci Yusuf. Oleh karena itu kalau mendapat mimpi yaitu visi dan misi kita, jangan sampai ada yang tahu sekalipun saudara, mereka akan menghancurkan mimpi itu, visi dan misi itu dan bahkan kehidupanmu akan dihancurkan. Sakit hati itu yang membuat mereka berbuat yang tidak benar. Buanglah sakit hatimu karena dengan demikian kamu akan menerima Wahyu Allah.

Mimpi adalah suatu metode Allah yang gunakan untuk berbicara kepada hamba-Nya. Yusuf mendapat mimpi menyuruh dia bangunlah dan pergi ke 
Yerusalem, dan Yusuf mengikuti mimpi itu sehingga Yusuf dan Maria dan juga Yesus di selamatkan dari pembunuhan. Ini adalah metode bahwa orang percaya kepada mimpi ditolong Tuhan. Orang yang berbicara untuk Allah yang menerima visi adalah: Abraham dalam Kitab Kejadian 15, Natan didalam Kitab 1 Tawarikh, Yeheskiel didalam Kitab Yehemia 1, dan juga Daniel di dalam Kitab kitab Daniel 8 (Enns 2010).

Roh Kudus adalah pembimbing dalam penulisan kitab Perjanjian Lama lewat manusia. Manusia dipakai Allah untuk menulis inspirasi atau wahyu Allah. Penulis Perjanjian Lama semuanya dibimbing oleh Roh Kudus sehingga apa yang tulis penulis tidak ada yang salah

Alkitab merupakan sumber kebenaran karena berisi firman Tuhan. Sebab itu hanya Alkitab yang mampu mendidik orang hidup dalam kebenaran serta memahami kehendak Allah dalam hidupnya. Alkitab adalah firman Allah yang tertulis. Ia adalah perwujudan penyataan Allah. Pertama-tama, Allah menyatakan diri-Nya dalam wahyu yang tertulis ini kepada umat Israel melalui nabi-nabinya dan penulis Alkitab yang dipercayakan oleh Tuhan untuk mendapatkan wahyu dan menuliskannya. Ini disebut Perjanjian Lama. Kemudian, Ia menyatakan diriNya melalui hubungan pribadi Yesus dengan murid-murid-Nya, penatua-penatua pada masa awal gereja dan penulis lainnya untuk menuliskan firman-Nya oleh ilham Roh Kudus, supaya berita tentang Yesus bahwa Ia adalah Tuhan dan Juru selamat tersebar keman-mana tempat diseluruh dunia. Ini disebut Perjanjian Baru, yang adalah kelanjutan dari Perjanjian Lama itu sendiri (Sibarani dan AS 2005). 
Dari sudut pandang Kristen, terbukti bahwa kesulitan para rasional berasal dari hal yang bersifat spritual. Seorang rasionalis mencari kepastian di luar Firman Allah. Ia mencari kriteria tertinggi tentang pikiran dalam ide dan penalaran deduktifnya sendiri. Dalam istilah Alkitab, pencarian rasionalis tersebut termasuk penyembahan berhala karena hal tersebut merupakan usaha pengilahan pikiran manusia. Pada waktu manusia mewujudkan allah-allah palsu dengan pikirannya, allah-allah itu pasti mengecewakan kita, jadi kita telah melihat bahwa pikiran logis manusia memang tidak mampu memberikan kumpulan pengetahuan tertentu bagi kita, pikiran rasional pasti membatasi jangkauannya hanya pada kebenarankebenaran paling abstrak yang sesungguhnya tidak memberikan pengetahuan tentang dunia nyata sama sekali.

Dengan demikian, hubungan antar Kitab Perjanjian Baru dan Perjanjian Lama dapat ditinjau dari sudut yang baru pula. Pada hampir tiap-tiap halaman kitab-kitab Injil ada kita baca: "sudah digenapi”. Yang baru itu sudah tiba untuk menggenapi yang lama. Tetapi bagaimana eratnya hubungan itu, dan bagaimana kebenaran Perjanjian Lama di wujudkan dan digenapi dalam jemaat perjanjian baru, hal itu barulah dinyatakan dengan jelas dalam surat-surat rasul-rasul. Paulus mengupas soal yang sulit ini dalam suratnya kepada jemaatdi Roma, pasal 9 sampai 11 dan seluruh surat kepada Ibrani mempersoalkan ini pula. Setiap bagian pernyataan Allah dalam Perjanjian Lama, seluruh sejarah Israel (ingat Kor.10, Ibr.11), dan hukum-hukum ibadat, semuanya disinari oleh terang cahaya Kristus sebagaimana tertuang dalam Yoh. 3:16 (Bavinck 1996). 
Kesaksian Alkitab tentang karya agung Allah mencakup kisah penciptaan dunia, sejarah umat Tuhan, dan kehidupan orang-orang saleh dan para nabi. Alkitab juga berisi hukum Tuhan bagi bangsa Israel dan seluruh umat manusia serta pernyataan diri-Nya melalui Yesus Kristus. Yesus sebagai seorang pemimpin di dalam Kerajaan-Nya (Hoekema 2004). Alkitab adalah Firman Tuhan, jadi jangan kita mengurangi atau menambahkan sesuatu kata di dalam Kitab Suci karena akam menyesatkan banyak orang dan juga kamu yang mengurangi atau menambahkan akan mendapat malapetaka dalam hidupmu seperti yang tertulis di dalam kitab ini (Why. 22:18,19).

Dalam Alkitab tergambar bahwa pengetahuan lahir dari pertemuan pribadi manusia dengan Allah. Pengenalan terhadap Allah didapatkan melalui pernyataan Allah dalam sejarah kehidupan manusia, baik di masa lalu maupun di masa kini. Pengenalan akan Allah tidak bisa terpisah dengan pernyataan Allah dalam ruang dan waktu, dalam konteks sejarah. Dalam Alkitab, pengetahuan ini mengimplikasikan kesadaran akan adanya hubungan yang spesifik dimana individu atau komunitas korporat berdiri bersama orang atau objek yang dikenalinya (Pazmino 2013). Semua makhluk diciptakan oleh Allah dan berada dalam pemeliharaan Allah. Kita dapat belajar berbagai aspek kebenaran hanya dalam kedaulatan Allah untuk mengungkapkan firman-Nya. Firman yang tertulis yang digenapi kelengkapannya dengan sangat komprehensif dan kebenaran sejati dalam segala bidang dan Roh Kudus membimbing manusia memahami firman Tuhan dalam konsep pewahyuan, kebenaran dan kekekalan. Alkitab dengan jelas 
BONAFIDE: Jurnal Teologi dan Pendidikan Kristen

www.jurnal.sttissiau.ac.id/Volume 2/Nomor 1/Juni 2021/hal. 25-45

mengatakan bahwa nubuat tidak boleh kamu tafsirkan menurut kehendak bebasmu (2 Ptr. 1:20-21) (Tung 2015). kehidupan Roh Kudus membimbing pewahyuan Alkitab dalam proses pembelajaran pada pendidikan Kristen. Roh Kudus membimbing anak untuk belajar memahami dan mentaati kebenaran. Roh Kebenaran mengungkapkan kemuliaan Tuhan Yesus Kristus. Setiap kebenaran harus dapat memenuhi panggilan dan rencana Allah dalam kehidupan manusia.

Karena kasih-Nya Allah datang ke dalam dunia untuk menyelamatkan manusia. Ingatlah bahwa Paulus sedang membandingkan, bukan hanya Perjanjian Lama dengan Perjanjian Baru, melainkan juga pelayanan Perjanjian Lama dengan Pelayanan kasih karunia. Tujuan pelayanan Perjanjian Lama adalah ketaatan kepada standar eksternal, tetapi ketaatan ini tidak dapat mengubah karakter manusia. Tujuan pelayanan Perjanjian Baru adalah menjadi serupa dengan Yesus Kristus. Hukum Taurat dapat membawa kita kepada Kristus (Gal. 3:24), tetapi hanya kasih karunia yang dapat membuat kita menyerupai Kristus.

Melalui kitab Yesaya ditunjukkan bahwa janji keselamatan secara khusus diberikan kepada orang-orang pilihan. Murid-Nya hanya akan diambil-Nya dari antara mereka, bukan dari seluruh manusia (Yes. 8:16) (Calvin 2000). Firman menyapa semua orang, namun karunia iman hanya didapatkan orang-orang pilihan. Iman itu memang pantas dihubungkan dengan pemilihan.

Sarana untuk pelayanan Perjanjian Baru adalah Hukum Taurat, tetapi sarana pelayanan Perjanjian baru adalah Roh Allah dengan menggunakan firman Allah. Karena Roh Kudus yang menulis firman Allah, maka Ia dapat 
BONAFIDE: Jurnal Teologi dan Pendidikan Kristen

www.jurnal.sttissiau.ac.id/Volume 2/Nomor 1/Juni 2021/hal. 25-45

mengajarkannya kepada kita, maka Ia dapat memampukan kita menaati firman Allah dari dalam hati kita. Ini bukan ketaatan kepada hukum karena ketakutan, melainkan ketaatan seperti anak-anak karena kasih. Akhirnya, hasil dari pelayanan Perjanjian yang Lama adalah Perbudakan, tetapi hasil dari Pelayanan yang Baru adalah kemerdekaan di dalam Roh. Legalisme membuat orang menjadi tidak dewasa, dan orang tidak dewasa harus hidup dengan hukum dan peraturan (lihat Gal. 4:1-7). Allah ingin anak-anak-Nya taat bukan karena hukum eksternal (hukum Taurat), melainkan karena karakter internal. Orang benar tidak mempunyai kehidupan didunia hukum Taurat, tetapi bukan berarti kita hidup tanpa aturan! Roh Allah menuliskan firman Allah di dalam hati kita, dan kita menaati Bapa kita karena Ia telah memberikan kehidupan yang baru dalam kita (Wiersbe 2014). Yang dimaksudkan dengan "hukum Taurat" bukanlah seluruh kitab Perjanjian Lama, melainkan selutuh sistem hukum atau undang-undang yang diberikan oleh Musa. Tentu saja Roh Kudus dapat memakai Perjanjian Lama maupun Perjanjian Baru untuk mengungkapkan Yesus Kristus kepada kita.

\section{KESIMPULAN}

Alkitab adalah dasar, pusat, dan maksud dalam pengajaran PAK karena hanya Alkitab yang berisi Injil, yaitu kabar baik tentang Juruselamat yang menebus segala dosa supaya manusia diperdamaikan pula dengan Allah. Pendidikan agama Kristen sangat berperan dalam kehidupan sehari-hari dan membawa perubahan dalam kehidupan sehari-hari. Tujuan deskripsi makna Pendidikan Agama Kristen dalam Kitab Suci terdiri atas: Pertama, pengetahuan 
BONAFIDE: Jurnal Teologi dan Pendidikan Kristen

www.jurnal.sttissiau.ac.id/Volume 2/Nomor 1/Juni 2021/hal. 25-45

yang didapat adalah orang percaya yang selalu mengandalkan Tuhan di dalam hidupnya dan tidak bercacat sehingga mereka menerima Wahyu Allah. Wahyu Allah mempengaruhi setiap orang, baik orang percaya maupun bukan orang percaya. Kata-kata dalam Wahyu begitu berbobot dan mempunyai kuasa. Bila orang sakit mendengar Wahyu Allah maka orang sakit itu akan sembuh.

Kedua, mengenal Yesus Kristus. Orang yang mengenal Yesus berarti memiliki hidup di dalam Tuhan, sebab Yesus berkata inilah hidup yang kekal. Pendidikan Agama Kristen berusaha mempertemukan manusia dengan Allah, mulai dari lingkup keluarga, gereja, hingga ke masyarakat.

Ketiga, karena begitu besar kasih Allah akan dunia ini, sehingga Ia telah mengaruniakan Anak-Nya yang tunggal, supaya setiap orang yang percaya kepada-Nya tidak binasa, melainkan beroleh hidup yang kekal menerima janji yaitu menerima kehidupan kekal.

\section{DAFTAR PUSTAKA}

Antone, Hope S. 2015. Pendidikan Kristiani Kontekstual: Mempertimbangkan Realitas Kemajemukan dalam Pendidikan Agama. Jakarta: BPK Gunung Mulia.

Bavinck, J.H. 1996. Sejarah Kerajaan Allah 2. Jakarta: BPK Gunung Mulia.

Berkhof, Louis, dan Cornelius Van Til. 2013. Dasar Pendidikan Kristen. 5 ed. Surabaya: Momentum.

Boehlke, Robert R. 2016a. Sejarah Perkembangan Pikiran \& Praktek Pendidikan Agama Kristen 1. Jakarta: BPK Gunung Mulia.

Boehlke, Robert R. 2016b. Sejarah Perkembangan Pikiran \& Praktek Pendidikan Agama Kristen 2. Jakarta: BPK Gunung Mulia.

Calvin, Yohanes. 2000. Institutio Pengajaran Agama Kristen. Jakarta: BPK Gunung Mulia.

Cully, Iris V. 2011. Dinamika Pendidikan Kristen. Jakarta: BPK Gunung Mulia. 
BONAFIDE: Jurnal Teologi dan Pendidikan Kristen

www.jurnal.sttissiau.ac.id/Volume 2/Nomor 1/Juni 2021/hal. 25-45

Enns, Paul. 2010. The Moody Handbook of Theology: buku Pegangan Teologi jilid 1. Malang: Literatur SAAT.

Frame, John M. 1999. Doktrin Pengetahuan Tentang Allah. Malang: Literatur SAAT.

Groome, Thomas H. 2011. Cristian Religius Education-Pendidikan Agama Kristen: berbagi cerita dan visi kita. Jakarta: BPK Gunung Mulia.

Hadiwijono, Harun. 2003. Iman Kristen. Jakarta: BPK Gunung Mulia.

Hoekema, Anthony A. 2004. Alkitab Dan Akhir Zaman. Surabaya: Momentum.

Holmes, Arthur F. 2009. Segala Kebenaran adalah Kebenaran Allah. Surabaya: Momentum.

Homrighausen, E.G., dan I. H. Enklaar. 2015. Pendidikan Agama Kristen. Jakarta: BPK Gunung Mulia.

Lefebure, Leo D. 2003. Penyataan Allah, Agama dan Kekerasan. Jakarta: BPK Gunung Mulia.

Letham, Robert. 2008. Allah Trinitas dalam Alkitab, Sejarah, Teologi, dan Penyembahan. Surabaya: Momentum.

Lillback, David W. Hall and Peter A. 2008. Penuntun kedalam Theologi Institutes Calvin: Esai-esai dan Analisis. Surabaya: Momentum.

Pazmino, Robert W. 2013. Fondasi Pendidikan Kristen Sebuah Pengantar dalam Perspektif Injili. Jakarta: BPK Gunung Mulia.

Sibarani, Poltak YP, dan Bernard Jody AS. 2005. Beriman dan Berilmu Panduan Pendidikan Agama Kristen untuk Mahasiswa. Jakarta: Ramos Gospel.

Sugiyono. 2015. Metode Penelitian Dan Pengembangan(Research and Development). Bandung: Alfabeta.

Tohirin. 2012. Metode Penelitian Kualitatif dalam Pendidikan dan Bimbingan Konseling: Pendekatan Praktis untu Peneliti Pemula dan Dilengkapi Dengan Contoh Transkrip Hasil Wawancara serta Model Penyajian Data. Jakarta: Rajawali.

Tung, Khoe Yao. 2015. Menuju Sekolah Kristen Impian Masa Kini. Yogyakarta: ANDI Offset.

Wiersbe, Warren W. 2014. Kuat Didalam Kristus. Bandung: Yayasan Kalam Kudus. 